\title{
KEPERCAYAAN DIRI ORANG DENGAN HIV DI KALANGAN LELAKI YANG BERHUBUNGAN SEKS DENGAN LELAKI (LSL) DI KOTA BANDUNG
}

\author{
Rizkiyatuzzahro \\ Politeknik Kesejahteraan Sosial Bandung, Jl. Ir. H. Juanda No. 367, Dago, Bandung 40135, \\ rizkiyatuzahro@gmail.com \\ Moch Zaenal Hakim \\ Politeknik Kesejahteraan Sosial Bandung, Jl. Ir. H. Juanda No. 367, Dago, Bandung 40135, \\ jejenhkm@yahoo.com \\ Enung Huripah \\ Politeknik Kesejahteraan Sosial Bandung, Jl. Ir. H. Juanda No. 367, Dago, Bandung 40135, \\ hurip@hotmail.co.id
}

\begin{abstract}
The confidence that is put forward how this person views himself fully with agreement on self-concept. This research aims to examine the need for self, optimism of informants on the status of HIV informants, objectivity to problems that require, the ability to be responsible for informants, the rationality of informants to problems that require informants of people with HIV. The research method used is descriptive research method with qualitative. Data sources used are primary data sources and secondary data sources are determined using purposive techniques. Data collection techniques used in this indepth interviews, observations, and documentation studies. While the technique of checking the validity and data uses a credibility test that is triangulation. Analysis of the data used is data reduction, data display and conclusions. The results showed that people with HIV were quite good, superior in the aspect of objectivity to the problem being accounted for, the ability to be responsible for the informant, the rationality of the informant for the problem that needed the informant. However, based on the results of research on aspects of confidence in the ability of self and optimism of informants on the informant's HIV status is still not good enough. Based on this, the researcher recommends that efforts should be made in order to increase confidence in the ability of the self and optimism of People Living With HIV among Men who have Sex with Men (MSM) in the Indonesian Puzzle Association through counseling approaches and the establishment of the Self Help Group.
\end{abstract}

Keywords:

Confidence; Male Who Have Sex with Male (MSM); PLWHA; Counseling; Self Help Group

\footnotetext{
Abstrak

Kepercayaan diri yang dimaksud bagaimana orang tersebut memandang dirinya secara utuh dengan mengacu pada konsep diri. Penelitian ini bertujuan untuk mengkaji mengenai keyakinan terhadap kemampuan diri, optimisme informan terhadap status HIV informan, obyektivitas terhadap masalah yang dihadapi, Kemampuan bertanggungjawab informan,
} 
rasionalitas informan terhadap masalah yang dihadapi informan orang dengan HIV. Metode penelitian yang digunakan metode deskriptif dengan pendekatan kualitatif. Sumber data yang digunakan sumber data primer dan sumber data sekunder yang ditentukan dengan menggunakan Teknik purposive. Teknik pengumpulan data yang digunakan dalam penelitian ini adalah wawancara mendalam (in-depth interview), observasi, dan studi dokumentasi. Adapun Teknik pemeriksaan keabsahan dan data menggunakan uji kredibilitas yaitu triangulasi. Analisis data yang digunakan data reduction (data reduksi), data display (penyajian data), dan conclusion (penarikan Kesimpulan). Hasil penelitian menunjukkan bahwa kepercayaan diri orang dengan HIV cukup baik, terutama pada aspek obyektivitas terhadap masalah yang dihadapi, Kemampuan bertanggungjawab informan, rasionalitas informan terhadap masalah yang dihadapi informan. Namun, berdasarkan hasil penelitian bahwa aspek keyakinan terhadap kemampuan diri dan optimisme informan terhadap status HIV informan masih belum cukup baik. Berdasarkan hal tersebut, maka peneliti merekomendasikan perlu dilakukan upaya penanganan dalam rangka Peningkatan keyakinan terhadap kemampuan diri dan optimisme Orang Dengan HIV dikalangan Lelaki yang berhubungan Seks dengan Lelaki (LSL) di Perkumpulan Puzzle Indonesia melalui pendekatan konseling dan pembentukan Self Help Group

Kata Kunci:

Kepercayaan Diri; Lelaki yang berhubungan Seks dengan Lelaki (LSL); ODHA; Konseling; Kelompok Bantu Diri 


\section{PENDAHULUAN}

Human Immunodeficiency Virus (HIV) dan Acquired Immuno Deficiency Syndrome (AIDS) merupakan masalah terbesar yang dihadapi oleh dunia. Mereka yang tertular HIV tidak hanya orang dewasa tetapi juga di kalangan anak-anak di hampir semua negara di dunia tanpa kecuali Indonesia. Permasalahan HIV/AIDS di Indonesia dari tahun ke tahun semakin meningkat dengan angka kematian yang cukup tinggi dan permasalahan HIV/AIDS di Indonesia sudah menjadi perhatian pemerintah.

Permasalahan HIV/AIDS hampir dialami setiap negara di dunia, kasus resmi HIV/AIDS pertama kali ditemukan pada 1981 di Amerika Serikat, penyebabnya adalah hubungan seks tidak aman yang dilakukan khususnya pada kelompok laki-laki homoseksual. Dalam perkembangan selanjutnya penularan HIV terjadi pada kelompok lainnya yaitu Pengguna NAPZA jarum suntik, Pekerja Seks Komersial, Wanita dan Anak-anak. Menurut data World Health Organization (WHO) pada akhir 2017 sekitar 36.9 juta orang di dunia hidup dengan HIV/AIDS termasuk di Indonesia.

Kasus pertama HIV/AIDS di Indonesia ditemukan tahun 1987 di Bali, kasus HIV/AIDS tersebut dialami oleh seorang warganegara Belanda. Berdasarkan data Kementerian Kesehatan Republik Indonesia, sejak HIV/AIDS ditemukan di Indonesia hingga Juni 2017 terdapat 242.699 orang HIV Positif, dan AIDS sebanyak 87,453 orang.

Penyebaran HIV/AIDS di Indonesia semakin lama semakin meluas. Kementerian Kesehatan Republik Indonesia pada Juni 2017 memaparkan bahwa penyebaran HIV/AIDS tertinggi di Indonesia yaitu di Provinsi DKI Jakarta dengan 46.758 kasus, kemudian Provinsi Jawa Timur dengan 33.043 kasus,
Provinsi Papua dengan 25.586 kasus, Provinsi Jawa Barat dengan 24.650 kasus dan terakhir adalah Provinsi Jawa Tengah dengan 18.038 kasus. Berdasarkan data tersebut Provinsi Jawa Barat menempati urutan keempat tertinggi kasus HIV/AIDS di Indonesia. Hal tersebut tentunya sangatlah memprihatinkan.

Berdasarkan data Kementerian Kesehatan Republik Indonesia, persebaran HIV/AIDS di Indonesia salah satunya dari hubungan seksual sejenis atau homoseksual. Hubungan seksual sejenis/homoseksualitas merupakan relasi seks dengan jenis kelamin yang sama atau rasa tertarik dan mencintai pada orang-orang berjenis kelamin sama baik secara perasaan ataupun secara erotik, dengan atau tanpa hubungan fisik. Jumlah homoseksual di Indonesia semakin meningkat dari tahun ke tahun khususnya di kota-kota besar. Kota Bandung sendiri berdasarkan data dari Bidang Pengendalian Penyakit dan Penyehatan Lingkungan Dinas Kesehatan Kota Bandung tahun 2017, mencatat terdapat 6.576 jiwa lakilaki homoseksual/gay di Kota Bandung dari jumlah penduduk laki-laki sebanyak 1.202.024 jiwa.

Salah satu Lembaga Swadaya Masyarakat (LSM) di Kota Bandung yang menangani dan mengkoordinir Orang Dengan HIV/AIDS (ODHA) dikalangan Lelaki yang berhubungan Seks dengan Lelaki (LSL) yaitu Perkumpulan Puzzle Indonesia. Menurut Permensos Nomor 08 Tahun 2012 tentang kelompok minoritas menyatakan gay sebagai kelompok minoritas dengan kriteria yaitu mengalami gangguan keberfungsian sosial, mengalami diskriminasi dan marginalisasi, serta berperilaku seks menyimpang.

LSM ini telah mendirikan Kelompok Dukungan Sebaya (KDS) Perkumpulan Puzzle, sebagai wadah untuk saling berbagi 
informasi, pengalaman, kekuatan dan harapan ODHA dikalangan LSL. KDS ini juga memberikan pelayanan dan dukungan dari aspek dukungan emosional psikososial, dan spiritual. Diharapkan melalui kegiatan ini para ODHA dapat lebih percaya diri dan memiliki pola pikir yang positif sehingga bisa menjadikan individu yang mandiri dan memiliki prestasi.

Berdasarkan informasi dari Koordinator Kelompok Dukung Sebaya (KDS) Perkumpulan Puzzle, kasus-kasus HIV/AIDS yang menjadi dampingan Perkumpulan Puzzle penularannya adalah dari hubungan seks heteroseksual, hubungan seks homoseksual dikalangan laki-laki atau yang disebut dengan Lelaki yang berhubungan Seks dengan Lelaki (LSL), dan Penyalahgunaan NAPZA dengan pemakaian jarum suntik yang tidak steril. Namun mayoritas ODHA yang menjadi dampingan adalah ODHA dari kalangan Lelaki yang berhubungan Seks dengan Lelaki (LSL).

Permasalahan umum yang sering dirasakan oleh ODHA baik secara langsung maupun tidak langsung yaitu penderitaan secara fisik, psikis, dan sosial. Secara fisik, virus HIV tersebut menyerang sistem kekebalan tubuh sehingga mudah untuk terserang berbagai macam penyakit. Secara psikis (mental), ODHA merasakan tertekan dengan status HIV/AIDS yang dihadapinya sehingga membuat ODHA kurang percaya diri dengan statusnya sekarang ini. Secara sosial ODHA mendapat perlakuan diskriminasi yang ditujukan terhadap dirinya dari keluarga dan masyarakat karena dianggap membawa aib dan mencemarkan nama baik keluarga dengan berbagai bentuk penolakan seperti acuh, tidak peduli, prasangka buruk, stigma dan pengucilan diri baik dari keluarga maupun masyarakat.
Stigma dan diskriminasi terhadap ODHA berdampak bagi kehidupan ODHA, dimana ODHA akan merasa takut, khawatir, malu, stres bahkan depresi yang mengakibatkan ODHA enggan untuk berobat, membuka statusnya, serta merasa dibedakan dan dikucilkan yang akhirnya akan menyebabkan ODHA menurun kondisi kesehatannya bahkan sampai meninggal dunia. Hal tersebut dikarenakan ODHA tidak percaya diri dengan statusnya, sehingga ia memilih diam, menutup diri dan menjadi pemurung serta takut jika bersosialisasi dengan masyarakat sekitar dan tidak percaya diri menghadapi masa depan.

Kepercayaan diri merupakan salah satu aspek kepribadian penting pada seseorang. Tanpa adanya kepercayaan diri akan banyak menimbulkan permasalahan pada diri seseorang. Kepercayaan diri merupakan atribut yang paling berharga pada diri seseorang dalam kehidupan bermasyarakat, karena dengan kepercayaan diri, seseorang mampu mengaktualisasikan segala potensi dirinya. Hal ini sesuai dengan pendapat Lautser dalam Ghufron dan Rini (2010:34) yang mengatakan bahwa :

"Kepercayaan diri diperoleh dari pengalaman hidup. Kepercayaan diri merupakan salah satu aspek kepribadian yang berupa keyakinan akan kemampuan diri seseorang sehingga tidak terpengaruh oleh orang lain dan dapat bertindak sesuai kehendak, gembira, optimis, cukup toleran, dan bertanggung jawab."

Menurut Rahmat (2015) kepercayaan diri diartikan sebagai suatu kepercayaan terhadap diri sendiri yang dimiliki oleh setiap orang dalam kehidupannya serta bagaimana orang tersebut memandang dirinya secara utuh dengan mengacu pada konsep diri. 
Lebih lanjut Lautser dalam Ghufron dan Rini (2010) mengemukakan aspek-aspek kepercayan diri yaitu 1. Keyakinan kemampuan diri, adalah sikap positif seseorang tentang dirinya, dimana ia mampu secara sungguh-sungguh dan mempunyai keyakinan yang pasti terhadap apa yang telah dilakukannya. 2. Optimis, adalah sikap positif yang dimiliki seseorang yang selalu berpandangan baik dalam menghadapi segala hal tentang diri dan kemampuannya. 3. Objektif, yaitu memandang permasalahan atau sesuatu sesuai dengan kebenaran yang semestinya, bukan menurut kebenaran pribadi atau menurut dirinya sendiri. 4. Bertanggungjawab, adalah kesediaan orang untuk menanggung segala sesuatu yang telah menjadi konsekuen-sinya, dan 5. Rasional dan realistis, yaitu analisis terhadap suatu masalah, dimana sesuatu hal dan suatu kejadian dianalisa dengan mengunakan pemikiran yang dapat diterima oleh akal dan sesuai dengan kenyataan.

Kepercayaan diri dilihat dari lima aspek diatas dijelaskan bahwa orang yang percaya diri akan yakin terhadap kemampuan dirinya walaupun ia memiliki kekurangan, optimis dalam menjalani kehidupannya baik yang sedang dijalani atau dimasa yang akan datang serta selalu berpandangan positif terhadap dirinya maupun lingkungan serta kemampuannya. Selain itu, orang yang percaya diri juga akan memiliki keobjektifan dan akan bertanggungjawab serta menerima segala resiko yang dihadapinya dan akan bertanggungjawab serta menerima segala resiko yang didapatkan akibat perbuatannya ataupun akibat permasalahan yang ia hadapi.

Rasa percaya diri tidak datang secara alami dibentuk oleh lingkungan dan juga pengalaman hidup yang pernah di alami oleh individu. Namun, apabila ada pemahaman yang negatif tentang diri sendiri maka akan membuat orang tersebut menjadi rendah diri atau kurang percaya diri terhadap segala kemampuan yang ia miliki.

Pentingnya kepercayaan diri pada Orang Dengan HIV/AIDS membuat adanya rasa yakin dan positif dalam menjalani kehidupan yang terbebani karena adanya penyakit tersebut. Pada dasarnya ODHA dengan orang-orang pada umumya tidak berbeda, bahkan apabila ODHA rajin menjaga kesehatan dan patuh menjalani pengobatan dan terapi AntiRetroviral (ARV) maka ia akan mengalami sehat, tidak akan mengalami gejala-gejala atau infeksi yang disebabkan oleh kondisi AIDS. Oleh karena itu, seharusnya ODHA tidak merasa rendah diri ketika ia bersosialisasi dengan masyarakat umum disekitarnya.

ODHA dikalangan LSL seringkali dihadapkan pada masalah kepercayaan diri. Karena menerima penolakan dari keluarga dan lingkungan tempat tinggalnya, tidak sedikit ODHA-LSL menyembunyikan statusnya. Mereka tidak melanjutkan ke jenjang pendidikan yang lebih tinggi karena malu. Belum lagi mereka seringkali dihadapkan kondisi fisik, kesehatan, pandangan dan sikap lingkungan sosial yang belum bisa menerima dan masih memberikan cap buruk yang berujung kepada stigma dan diskriminasi, menyebabkan kurangnya kepercayaan diri ODHA (Soetjinigsih dalam Fauziyah, Zahroh, \& Priyadi, 2018).

ODHA dikalangan LSL maupun kalangan Pekerja Seks dan Penyalahguna NAPZA jarum suntik sering mendapatkan stigma dan diskriminasi di masyarakat. Warga masyarakat menilai mereka layak tertular HIV akibat kesalahan sendiri karena perilakunya 
melanggar norma-norma masyarakat (Baba dalam Moch Zaenal Hakim, 2019). Isu stigma dan diskriminasi bukanlah masalah satusatunya yang dihadapi ODHA, DuBois dan Miley (2014) mengemukakan masalah lainnya yang dihadapi ODHA adalah terkait continuining their everyday lives, deal with loss, planning for survivors, dan special issues for women.

Permasalahan terkait dengan kepercayaan diri juga dialami oleh ODHA dari kalangan LSL di KDS Perkumpulan Puzzle kota Bandung. Berdasarkan hasil wawancara dengan Koordinator KDS Puzzle, diperoleh informasi bahwa, meskipun telah dilakukan berbagai kegiatan dampingan, para ODHALSL masih memiliki kepercayaan diri yang kurang. Hal ini dapat dilihat ketika melaksanakan kegiatan dengan warga sekitarnya, mereka nampak kurang percaya diri. Para ODHA juga belum yakin dengan masa depannya dan seringkali mengalami permasalahan fisik, mental emosial, sosial dan spiritual. Kondisi ini akan mempengaruhi kesehatan ODHA dan akan semakin berdampak juga pada kondisi psikososialnya.

Berdasarkan latar belakang masalah diatas, peneliti tertarik untuk melakukan penelitian untuk mengetahui lebih lanjut tentang kepercayaan diri orang dengan HIV dikalangan LSL. Judul penelitian adalah "Kepercayaan Diri Orang dengan HIV dikalangan Lelaki yang berhubungan Seks dengan Lelaki (LSL) di Kota Bandung”.

\section{METODE}

Metode penelitian yang digunakan untuk meneliti kepercayaan diri orang dengan HIV di kalangan LSL di Perkumpulan Puzzle Kota Bandung adalah kualitatif dengan desain deskriptif. Penelitian Kualitatif menurut
Moleong (2011) yaitu penelitian yang menghasilkan prosedur analisis yang tidak menggunakan prosedur analisis statistik atau cara kuantifikasi lainnya. Penelitian kualitatif dengan desain deskriptif menghasilkan dan mengolah data yang sifatnya deskriptif seperti transkrip wawancara, catatan lapangan, dan dokumentasi kegiatan. Teknik penentuan informan dilakukan dengan teknik purposive, yaitu cara menentukan sumber data dengan memilih informan berdasarkan kriteria yang ditetapkan sesuai dengan ketersediaan data di lapangan. Peneliti menentukan informan dengan beberapa kriteria/pertimbangan sebagai berikut:

1. Koordinator Kelompok Dukungan Sebaya (KDS), yaitu Koordinator Kelompok Dukungan Sebaya (KDS) di Puzzle Kota Bandung yang menjadi pendamping ODHA - LSL.

2. Orang Dengan HIV dari kalangan LSL:

a. Berusia di bawah 35 tahun.

b. Terinfeksi HIV kurang 4 tahun.

c. Memiliki latar belakang dan pengalaman terkait dengan isu psikososial baik dari keluarga maupun dari masyarakat yang mempengaruhi kepercayaan diri ODHA

d. Mampu berkomunikasi dengan baik dan bersedia menjadi informan penelitian.

Berdasarkan kriteria diatas, diambil 4 informan ODHA - LSL, dan satu Informan dari Pendamping KDS Puzzle. Penentuan ini didasarkan bahwa dalam penelitian kualitatif tidak dilihat pada jumlah informan tetapi lebih pada kelengkapan dan kedalaman data informasi yang diperoleh sehingga mencapai titik jenuh melalui wawancara mendalam (Indepth Interview). 


\section{HASIL PENELITIAN}

Hasil penelitian memuat tentang karakteristik informan, keyakinan akan kemampuan diri, optimis informan terhadap status HIV/AIDS, obyektif informan terhadap masalah yang dihadapi, kemampuan bertanggung jawab informan, rasional informan terhadap masalah yang dihadapi. Berikut merupakan penjelasan dari hasil penelitian yang telah dilakukan oleh peneliti.

\section{Karakteristik Informan Penelitian}

Informan dalam penelitian ini berjumlah lima orang yang terdiri dari empat orang Informan ODHA dikalangan LSL dan satu Pendamping Kelompok Dukungan Sebaya (KDS) Puzzle. Berikut tabel informan dalam penelitian:

Tabel 1 Karakteristik Informan

\begin{tabular}{cllll}
\hline Nama & Usia & Agama & Pend & \multicolumn{1}{c}{ Kerja } \\
\hline T & 26 & Islam & D4 & - \\
\hline A & 32 & Islam & D3 & Swasta \\
\hline I & 32 & Islam & SMA & $\begin{array}{l}\text { Pemandu } \\
\text { Karaoke }\end{array}$ \\
\hline P & 25 & Islam & SMA & Swasta \\
\hline BY & 33 & Islam & SMA & Swasta \\
\hline
\end{tabular}

\section{a. Informan $T$}

Berusia 26 tahun dan beragama Islam. Saat ini belum bekerja dikarenakan $\mathrm{T}$ baru saja lulus kuliah program sarjana. "Saya baru lulus DIV teh kebetulan saya belum bekerja tapi lagi nunggu panggilan juga soalnya udah masuk beberapa $C V$ ke beberapa perusahan sih teh"

Sebelumnya $\mathrm{T}$ pernah bekerja part time semasa SMA sampai kuliah. Saat ini kondisi kesehatan $\mathrm{T}$ sangat baik. $\mathrm{T}$ berkacamata, berbadan kurus dan tinggi, serta memiliki kulit berwarna putih. Berat badan $\mathrm{T}$ sekitar $50 \mathrm{~kg}$ dengan tinggi 163 $\mathrm{cm}$. T memiliki rambut lurus, pendek dan berwarna hitam.

\section{b. Informan A}

Berusia 32 tahun, beragama Islam, dan Pendidikan terakhir D-III. Saat ini berkerja sebagai pendamping bagi teman-teman ODHA yang Pekumpulan Puzzle.

"Saya sekarang kerja sebagai pendamping KDS bagi teman-teman di Perkumpulan Puzzle dan kadang saya diminta membantu teman-teman ODHA yang lainnya kaya ibu-ibu yang terinfeksi HIV karena ulah suami yang jajan diluar sih teh"

Informan A bekerja sebagai pendamping bagi teman-teman KDS di Puzzle maupun

ODHA yang lainnya. Selain itu sekarang kondisi kesehatan A sedang sehat, badannya gemuk dan tinggi, serta memiliki kulit berwarna hitam, dan berhidung mancung, Berat badan A $64 \mathrm{~kg}$ dengan tinggi 164 $\mathrm{cm}$. Informan memiliki rambut lurus, pendek dan berwarna putih karena dicat.

\section{c. Informan I}

Berusia 32 tahun. dan beragama Islam, Informan I terkadang masih menjalankan ibadah seperti sholat meskipun tidak lima waktu. Pendidikan terakhir SMA, dan sekarang bekerja sebagai pegawai karaoke di Bandung.

"Saya sekarang kerja sebagai pegawai Karaoke teh di sekitar sini biasanya saya berangkat dari malem baru pulang subuh teh"

Informan bekerja adalah untuk memenuhi kebutuhan sehari-hari, seperti membayar uang kontrakan, makan, dan membiayai anak angkat I. Sekarang kondisi kesehatan Informan I 
sedang sehat. Badannya kurus dan tinggi, serta memiliki kulit sawo matang, serta berat badan sekitar $47 \mathrm{~kg}$ dengan tinggi $170 \mathrm{~cm}$. Informan memiliki rambut sedikit bergelombang, pendek dan berwarna hitam

\section{d. Informan P}

Berusia 25 tahun dan bergama Islam, Informan P lahir dan tinggal di Bandung. Pendidikan terakhir P yaitu SMA, saat ini dia berkerja Freelance.

"Saya sekarang kerjanya freelance sih teh hehehe makanya saya banyak waktu dan kadang suka datang main kesini kalo ada panggilan baru kerjasih teh"

Kondisi kesehatan $\mathrm{P}$ saat ini terlihat sehat, badan kurus dan tinggi, serta memiliki kulit berwarna sawo matang. Berat badan P sekitar $59 \mathrm{~kg}$ dengan tinggi $169 \mathrm{~cm}$, memiliki rambut lurus, pendek dan berwarna hitam.

\section{e. Informan BY}

Informan adalah merupakan Koordinator Kelompok Dukungan Sebaya (KDS) Perkumpulan Puzzle Indonesia Kota Bandung, berusia 33 tahun. Informan bertugas sebagai fasilitator untuk menjangkau teman-teman KDS agar mau tes HIV, minum obat teratur, dan mensosialisasikan HIV/AIDS baik ke teman-teman ODHA maupun ke masyarakat.

"Saya di Puzzle ini sebagai koordinator bagi temen-temen KDS yang ada diPuzzle dan biasanya saya tugasnya lebih kepenjangkauan temen KDS, memotivasi KDS yang lainnya supaya mau minum obat dan berobat rutin, terus bantuin temen-temen yang lagi dalam masalah juga sih teh"

Informan membantu teman-teman KDS yang sedang mengalami permasalahan baik itu stigma atau diskriminasi yang didapat yang nantinya di Advokasi, dan sering memberikan dukungan kepada teman-teman KDS Puzzle

\section{Keyakinan akan Kemampuan Diri}

Keyakinan dimaksud adalah sikap percaya atau sungguh-sungguh orang dengan HIV yang berorientasi LSL tentang dirinya, kemampuannya dan tentang apa yang dilakukannya, sehingga ia merasa yakin dengan kemampauan dirinya sebagai orang dengan HIV untuk beraktivitas sehari-hari layaknya orang lain yang ada di sekitarnya. Hasil wawancara dengan informan tentang keyakinan akan kemampuan diri untuk menjalani hidup dengan status HIV beragam. Hasil penelitian menunjukkan bahwa dari keempat informan tersebut, terdapat dua informan yang sudah memiliki keyakinan terhadap kemampuannya yaitu $\mathrm{A}$ dan I, sementara dua informan lainnya yaitu $\mathrm{T}$ dan $\mathrm{P}$ kurang memiliki keyakinan terhadap kemampuannya. Hal tersebut terlihat dari antusiasme dan keyakinan Informan dalam menjawab pertanyaan, sementara yang lainnya terlihat tidak yakin dan ragu-ragu dalam menjawab pertanyaan. Dari dua informan yang merasa kurang yakin dengan kemampuannya, menyatakan apabila ada yang mengetahui status HIVnya akan menghambat dan mengganggu informan dalam menjalan aktivitas seharihari. Sementara sebagian informan lainnya yang merasa yakin terhadap kemampuan dirinya untuk bisa hidup dengan status HIV merasa tidak ada mengalami hambatan. Mereka mempunyai pemikiran bahwa selama ini mereka tidak merugikan warga masyarakat disekitar-nya dan yakin mampu menjalani hidup yang lebih baik dan normal 
meskipun dengan status HIV positif. Kondisi ini didukung oleh informan BY sebagai pendamping keempat Informan. Informan BY mengemukakan bahwa kondisi yang dialami oleh Informan $\mathrm{T}$ dan Informan P, disebabkan karena mereka belum bisa terbuka kepada sesama ODHA LSL lainnya didalam berbagai kegiatan yang dilaksanakan oleh KDS Puzzle. Informan T dan $\mathrm{P}$ juga, karena akan berdampak buruk apabila status HIVnya diketahui orang lain, belum dapat membuka diri atau open status HIV nya kepada orang lain. .

\section{Optimis Informan terhadap Status HIV/AIDS}

Optimis yang dimaksud disini adalah sikap positif ODHA dikalangan LSL yang selalu berpandangan baik tentang dirinya, kondisinya dan tentang apa yang ia hadapi dan selalu berusaha agar selalu bersikap positif.

Berdasarkan beberapa pernyataan informan mengenai optimisme informan terhadap status HIV yang dimilikinya menunjukan hasil yang berbeda. Informan A dan I merasa optimis serta berpandangan baik atau positif tentang dirinya dan kondisinya ketika ada yang memberikan dukungan dan motivasi kepadanya dalam menjalani hidup dengan status HIV. Sedangkan dua informan lainnya yaitu $\mathrm{T}$ dan $\mathrm{P}$, merasa belum optimis dengan status HIV akan tetapi mencoba untuk optimis walaupun harus melalui proses yang lama untuk dapat merasa optimis dengan keaadannya status HIVnya. Informan BY mengemukakan bahwa Informan $\mathrm{T}$ dan $\mathrm{P}$ belum memiliki keyakinan dan optimis sekuat yang dimiliki oleh Informan A dan Informan I. Hal ini dikarenakan mereka baru terlibat aktif didalam KDS dibandingkan dengan
Informan A dan I yang sudah lama mengikuti kegiatan pendampingan yang dilaksanakan oleh KDS. Perlu upaya pendampingan yang lebih kepada Informan $\mathrm{T}$ dan $\mathrm{P}$, agar meningkat optimisme dan keyakinan dengan hidup sebagai HIV positif..

4. Obyektif informan terhadap masalah yang dihadapi

Objektif yang dimaksud adalah pandangan ODHA terhadap permasalahan yang dihadapi sesuai dengan kebenaran yang semestinya atau bukan menurut kebenaran pribadi atau menurut dirinya sendiri.

Berdasarkan jawaban informan T, P, I dan A diperoleh gambaran bahwa sebagian besar informan telah memandang secara objektif permasalahan yang dihadapi berkaitan dengan HIV khususnya stigma yang dirasakan tiap-tiap informan. Terdapat informan yang memandang stigma yang mereka alami adalah sesuatu yang wajar meskipun stigma itu menyakiti perasaan informan.

Mereka merasakan bahwa status mereka sebagai LSL, telah lama mengalami penolakan dari masyarakat dan seringkali mereka juga mengalami diskriminasi baik dari keluarga maupun lingkungan sekitar tempat tinggalnya. Hal itu semakin meningkat ketika mereka juga sekarang telah berstatus HIV positif. Informan memandang hal ini secara objektif sedang mereka alami. Mereka menerima kondisi ini, tetapi sekaligus juga merasa perlu untuk bertindak dan bisa memperjuangkan bagaimana agar keluarga dan masyarakat tidak selamanya memberikan stigma dan diskriminasi kepada mereka.

Lebih lanjut Informan BY sebagai pendamping ODHA - LSL mengemukakan 
bahwa mereka menyadari situasi dan kondisi yang mereka alami menjadikan masyarakat dan bahkan keluarga mereka sendiri merasa terancam dan memandang negatif terhadap status mereka. ODHA - LSL pada dasarnya ingin masyarakat juga memahami bahwa kondisi dan status ODHA mereka saat ini adalah bukan yang mereka kehendaki. Oleh karena itu, Informan juga berharap masyarakat juga memahami dan memberikan solusi terhadap permasalahan yang mereka hadapi.

5. Kemampuan Informan

Bertanggungjawab yang dimaksud disini adalah sikap informan yang positif HIV dalam menerima segala hal serta dampak yang dialami setelah ia terinfeksi HIV.

Berdasarkan jawaban informan P, I, A dan T tentang kemampuan bertanggungjawab informan dalam menerima segala dampak setelah terinfeksi HIV, seluruh Informan memiliki kemampuan bertanggungjawab yang baik. Informan menerima dampak yang dirasakan akibat terinfeksi HIV walaupun terdapat rasa menyesal. Adapun dampak yang dirasakan lebih kepada kondisi kesehatan mereka yang berkurang, menghargai hidup dan mengurangi perilaku seks yang beresiko. Selain itu, juga informan menyesali akibat perbuatannya yang telah melakukan hubungan seks yang beresiko yang menyebabkan informan terinfeksi HIV. Mereka menilai ini adalah tanggung jawab mereka dan bukan karena disebabkan oleh kesalahan dan perbuatan orang lain.

Kondisi ini akan sangat mendukung dalam proses pendampingan yang dilaksanakan oleh KDS Puzzle. Menurut Informan BY, selama ini para anggota KDS mendapatkan berbagai program dan kegiatan pendampingan yang diarahkan kepada upaya untuk memberikan keyakinan dan penerimaan diri ODHA terhadap statusnya, serta memiliki rasa tanggung jawab pribadi atas segala apa yang terjadi yang menjadikan mereka berstatus HIV Positif. Dengan adanya rasa tanggung jawab ini, akan mempermudah proses pendampingan, sehingga membantu mereka untuk dapat secara aktif berupaya memperbaiki diri, baik secara sendiri maupun secata kelompok dengan sesama ODHA-LSL, untuk meningkatkan hidup dan kehidupannya yang lebih baik di masa depan.

Rasa penyesalan dikalangan Informan juga menunjukkan bahwa Informan peduli terhadap dirinya sendiri. Mereka menyadari melakukan kesalahan dan menyesal, tetapi kekesalan itu mereka kembalikan kepada diri mereka sendiri bahwa mereka harus dapat menghadapi secara bertanggungjawab.

\section{Rasional Informan terhadap masalah} yang dihadapi

Rasional yang dimaksud disini adalah sikap seseorang, dalam hal ini adalah ODHA, mampu menganalisis masalah dengan menggunakan pemikiran yang dapat diterima oleh akal sehat dan sesuai dengan kenyataan.

Berdasarkan jawaban informan terkait dengan rasional terhadap permasalahan yang dihadapi, seluruh informan mampu menganalisis permasalahan sesuai kenyataan dan membuat keputusan untuk solusi permasalahannya secara realistis atau masuk akal. Selain itu, permasalahan yag mereka alami sebagai dampak dari status HIV Positif, dihadapi dengan pemikiran yang dapat diterima sehingga mereka paham 
bagaimana mereka dapat memecahkan permasalahan tersebut.

Informan BY menambahkan rasional Informan ODHA terhadap permasalahan yang mereka hadir terlihat dari pemikiranpemikiran mereka terkait dengan kondisi yang mereka alami. Mereka menyadari bahwa mereka terinfeksi HIV, sehingga mereka memiliki pemahaman apabila mereka tidak teratur meminum obat, tidak rutin memeriksakan kesehatannya dan tetap berperilaku yang berisiko tinggi, pasti kondisinya akan bertambah parah. Informan BY juga menilai para Informan memahami bahwa mereka tidak boleh menularkan virusnya kepada orang lain. Apapun alasannya, menurut penilaian Informan BY, para Informan ODHA sadar bahwa mereka justru harus mampu melakukan pencegahan penularan virus HIV yang ada didalam tubuhnya kepada orang lain baik kepada pasangan, keluarga ataupun masyarakat disekitar tempat tinggalnya. Selain itu juga, para Informan ODHA merasa bahwa mereka juga bisa memberikan informasi dan edukasi kepada masyarakat umum supaya tidak tertular HIV dengan tidak berperilaku berisiko tinggi terinfeksi dan mengetahui berbagai upaya pencegahan yang dapat dilakukan.

\section{PEMBAHASAN}

Berdasarkan deskripsi hasil penelitian dari aspek keyakinan akan kemampuan diri, optimis informan terhadap status HIV/AIDS, obyektif informan terhadap masalah yang dihadapi, kemampuan bertanggung jawab Informan, dan rasional informan terhadap masalah yang dihadapi, maka selanjutnya akan diuraikan pembahasan hasil penelitian meliputi analisis penelitian, analisis masalah, analisis kebutuhan dan analisis sistem sumber.

\section{Analisis Hasil Penelitian}

\section{a. Keyakinan akan kemampuan diri}

Keyakinan terhadap kemampuan diri adalah penilaian diri sendiri tentang seberapa besar ia mampu untuk mengatasi kemampuan yang dimiliki dengan status HIV. Hal tersebut sesuai dengan pendapat lautser dalam Ghufron dan Rini (2010) bahwa keyakinan kemampuan diri adalah sikap positif seseorang tentang dirinya dan mampu secara sungguh-sungguh meyakini apa yang dilakukannya.

Berdasarkan hasil penelitian, Informan T, P, I dan A memiliki keyakinan terhadap kemampuan diri yang cukup beragam, yaitu ada yang sudah yakin akan kemampuannya dan ada pula yang belum yakin bahwa mereka dapat bertahan hidup dengan status HIV positif. Mereka yang belum dapat memberitahukan status HIV kepada lingkungan sekitar lebih cenderung merasa tidak yakin dengan kemampuan dirinya apabila orang dilingkungan sekitarnya mengetahui status HIVnya. Informan lainnya merasa yakin, meskipun statusnya dikehui orang lain, tidak akan berpengaruh terhadap keyakinan bahwa dirinya mampu menjalani kehidupan yang lebih baik.

A dan I merasa bahwa ia memiliki keyakinan terhadap kemampuan diri dan mampu membuka statusnya kepada keluarga, lingkungan disekitarnya, mau bergaul dengan masyarakat sekitar. Selain itu, ia juga mau bergaul dengan masyarakat sekitar seperti tetangga rumah dan tempat bekerjanya, hal ini menunjukan bahwa A dan I tidak merasa 
terhambat oleh status HIVnya, maka bisa dikatakan bahwa informan sudah memiliki keyakinan terhadap kemampuan diri untuk dapat hidup dengan HIVnya.

Berbeda dengan $\mathrm{T}$ dan $\mathrm{P}$ yang memiliki keyakinanan akan kemampuan dirinya bahwa mereka dapat hidup dengan HIV akan tetapi apabila terdapat orang disekitarnya mengetahui nantinya dapat membuat informan $\mathrm{T}$ dan $\mathrm{P}$ merasa tidak yakin dengan kemampuannya. Hal ini disebabkan penilaian negatif tentang dirinya yang terinfenksi HIV yang berakibat denga kemampuan diri sendiri bahwa ia tidak dapat menjalani hidup dengan status HIV positif. Kondisi ini akan menimbulkan perasaan takut, cemas, serta tertekan. Mereka masih merasa cemas terutama terhadap ketahuan karena mereka terinfeksi HIV yang nantinya akan membuat mereka dijauhi dan dibenci oleh lingkungan sekitarnya. Hal tersebut menunjukan bahwa $\mathrm{T}$ dan $\mathrm{P}$ belum miliki keyakinan terhadap kemampuannya.

\section{b. Optimis Informan terhadap status HIV/AIDS}

Optimis Informan terhadap status HIV terkat dengan sikap positif yang ditunjukkan kepada lingkungan sekitar dan berpandangan baik terhadap apa yang dilakukannya. Hal tersebut sesuai dengan pendapat lautser dalam Ghufron dan Rini (2010) bahwa optimis adalah sikap positif yang dimiliki seseorang yang selalu berpandangan baik dalam menghadapi segala hal tentang diri dan kemampuannya. Berdasarkan hasil penelitian bahwa rasa optimis yang dimiliki Informan cukup beragam, ada yang sudah memiliki rasa optimis yang baik dan ada pula yang belum memiliki rasa optimis dalam dirinya. Informan A dan I memiliki rasa optimis yang baik menunjukkan sikap dan pandangan yang positif terhadap statusnya. Mereka mendapatkan dukungan dari temanteman sesama ODHA, mampu berkerja dengan baik, dapat selalu menjaga kesehatan, minum obat teratur dan selalu memotivasi dirinya sendiri agar selalu bersikap optimis serta berpandangan baik terhadap dirinya.

Namun sebaliknya, Informan yang belum memiliki rasa optimis dengan dirinya cenderung berpandangan negatif. Hal tersebut bisa menjadi hambatan kedepannya bagi informan yang belum memiliki rasa optimis, bahwa meskipun dirinya terinfeksi HIV bukan berarti ini adalah akhir dari segalanya tetapi harus terus dibarengi dengan berbagai upaya yang positif untuk tidak mengalami kondisi yang lebih parah lagi.

Berdasarkan hasil penelitian bahwa salah satu faktor yang mempengaruhi optimis informan adalah adanya dukungan dari luar atau motivasi dari pihak luar baik itu keluarga, rekan sebaya serta lingkungan sekitar. Faktor dari luar sangat mempengaruhi bagaimana informan memandang dirinya serta kondisi yang ia alami seperti keluarga atau teman yang selalu memberikan motivasi terhadap diri informan, mengingatkan untuk selalu menjaga kesehatan dan minum obat. Hal tersebut dapat mempengaruhi optimis informan untuk menjalani hidup dengan status HIV positif.

Hasil penelitian menunjukkan terdapat dua informan yang belum dapat atau ragu 
dengan rasa optimis yang mereka miliki, yaitu $\mathrm{P}$ dan $\mathrm{T}$. Mereka memiliki rasa ketakutan apabila mereka membuka status HIV dan adanya rasa penyesalan yang cenderung berpandangan negatif tentang dirinya karena terinfeksi HIV. Informan mencoba untuk optimis dengan cara mengikuti kegiatan diskusi dengan teman-teman sesama anggota KDS, mencoba menerima dan memotivasi dirinya agar kedepannya dapat lebih optimis.

c. Obyektif terhadap masalah yang dihadapi Informan

Hasil penelitian menunjukkan obyektivitas Informan terhadap masalah yang dihadapi dilihat dari cara memandang permasalahan tidak hanya berdasarkan kebenaran pribadi sendiri melainkan sesuai dengan kebenaran yang semestinya. Hal tersebut sesuai pendapat lautser dalam Ghufron dan Rini (2010) bahwa orang memandang permasalahan atau sesuatu sesuai dengan kebenaran yang semestinya. Bukan menurut kebenaran pribadi atau menurut dirinya sendiri.

Hasil penelitian menunjukkan obyektivitas seluruh Informan sudah baik. Mereka dapat memandang permasalahan yang dihadapi sesuai dengan apa yang terjadi selain itu informan memandang permasalahannya tidak berdasarkan pemikirannya sendiri melainkan melihat dari sudat pandang lainnya seperti stigma yang dirasakan tiap-tiap informan. Informan memandang stigma yang mereka alami dikarenakan ketidaktahuan masyarakat tentang HIV/AIDS. Meskipun stigma itu menyakiti perasaan informan, namun hal ini tidak menjadikan mereka menstigma diri mereka sendiri. Justru hal ini menjadikan mereka berpandangan bahwa masyarakat harus diberikan pemahaman dan informasi yang lengkap dan benar terkait dengan penularan HIV/AIDS, sehingga stigma dan diskriminasi dengan sendirinya akan hilang.

\section{d. Kemampuan Bertanggungjawab Informan}

Menurut lautser dalam Ghufron dan Rini (2010), aspek tanggung jawab adalah kesediaan orang untuk menanggung segala sesuatu yang telah menjadi konsekuensinya Hasil penelitian menunjukkan bahwa tanggungjawab seluruh Informan cukup baik. Informan mau menerima segala dampak dan menjalani segala hal yang berkaitan dengan HIV yang meliputi kesehatan, menghargai hidup, aktivitas sehari-hari dan juga Informan dapat menerima berbagai dampak yang akan mereka hadapi.

Bentuk tanggungjawab Informan terhadap diri sendiri terlihat ketika peneliti mengunjungi KDS Puzzle, Informan A selalu berusaha mengkonsumsi obat secara teratur dan tepat waktu walaupun terkadang jenuh untuk mengkonsumsi ARV. Selain itu Informan A selalu mengingatkan teman KDS yang lain untuk minum obat tepat waktu dan rutin, menjaga pola makannya, istirahat yang cukup, dan juga berani menolak ajakan untuk berhubungan seks yang beresiko tinggi. Kemudian ada juga Informan yang membantu teman-teman HIV/AIDS yang lain untuk memotivasi agar mau minum obat kembali, mengajak untuk memeriksa ke rumah sakit ataupun 
Puskesmas, dan mendukung temanteman ODHA yang mendapatkan stigma atau diskriminasi.

\section{e. Rasional informan terhadap masalah yang dihadapi}

Rasional dan realitas adalah analisis terhadap suatu masalah. Sesuatu hal dan suatu kejadian dengan mengunakan pemikiran yang dapat diterima oleh akal dan sesuai dengan kenyataan Hal tersebut sesuai dengan pendapat Lautser dalam Ghufron dan Rini (2010). Rasional dan realistis yang ditunjukkan oleh seluruh Informan cukup baik dimana mampu menganalisis permasalahan sesuai kenyataannya dan membuat keputusan untuk solusi permasalahannya secara realistis atau masuk akal yang sedang ia alami dan memikirkan tindakan atau solusi seperti apa untuk memecahkan permasalahan tersebut.

Hasil penelitian menunjukkan Informan I dan A mengalami permasalahan kesehatan. Informan A merasa dirinya harus dapat mengendalikan pola makan agar tidak berlebihan yang dapat menimbulkan penyakit lainnya, sementara Informan I merasa dirinya mudah sekali sakit. Upaya yang dilakukan oleh Informan I yaitu mencoba membagi waktu beristirahat informan.

Permasalahan yang dialami Informan $P$ dan T lebih kepada belum sanggup untuk membuka statusnya HIV positifnya. Hal karena mereka menilai masyarakat kurang memahami tentang penularan dan isu-isu HIV/AIDS sehingga hal ini dapat memunculkan stigma dan diskriminasi masyarakat terhadap ODHA termasuk kepada diri Informan. Oleh karena ini Informan memilih memcoba memberikan pemahaman terlebih dahalu kepada masyarakat, dan apabila masyarakat sudah sadar dan mau memberikan dukungan dan perlindungan, informan akan membuka statusnya baik kepada keluarga, pasangan, teman, dan warga sekitarnya.

\section{Analisis Masalah, Kebutuhan dan Sistem} Sumber

Berdasarkan wawancara mendalam, observasi, dan studi dokumentasi, terdapat beberapa permasalahan dan hambatan pada kepercayaan diri orang dengan HIV dikalangan LSL di Perkumpulan Puzzle Indonesia. Hal ini terkait dengan keyakinan terhadap kemampuan diri, optimis terhadap status HIV, obyektivitas terhadap masalah, tanggungjawab, dan rasionalitas terhadap masalah yang dihadapi.

Permasalahan kepercayaan diri orang dengan HIV dikalangan LSL di Perkumpulan Puzzle Indonesia sebagai berikut:

\section{a. Kurangnya keyakinan akan kemampuan yang dimiliki}

Informan masih ada rasa ketakutan apabila nanti terdapat orang yang mengetahui statusnya dan ini bisa menjadi hambatan bagi Informan terhadap kemampuan yang dapat dilakukannya kedepan atau dapat membuat Informan tidak yakin akan kemampuan yang dimiliki.

\section{b. Belum terbuka terhadap status HIV Positif}

Informan belum dapat membuka statusnya terhadap keluarga, teman, calon pasangannya nanti. Mereka merasa takut untuk memnyampaikan bahwa mereka terinfeksi HIV karena kebanyakan orang masih banyak yang belum memahami apa itu HIV dan informan merasa takut apabila memberitahu statusnya akan membuat 
orang disekitarnya tidak menerima keadaannya sehingga akan berakibat tidak adanya dukungan dan perlindungan dari lingkungan sekitarnya.

Mengacu kepada permasalahan di atas, peneliti menyimpulkan kebutuhan yang perlu dipenuhi dalam upaya meningkatkan kepercayaan diri ODHA - LSL yaitu:

a. Pemberian motivasi baik keluarga maupun dari sesama anggota Kelompok Dukungan Sebaya (KDS)

b. Perlunya penguatan dari teman-teman ODHA lain bahwa orang dengan HIV dapat hidup layaknya orang normal.

Upaya-upaya yang dijelaskan diatas, perlu mendapatkan dukungan dari berbagai sistem sumber yang tersedia. Sistem sumber merupakan segala sesuatu yang dapat dipergunakan dan dimanfaatkan guna mengatasi permasalahan dan memenuhi kebutuhan. Beberapa sumber yang dapat digunakan menurut Pincus dan Minahan dalam Edi Suharto (2010) adalah sistem sumber informal, sistem sumber formal, sistem sumber kemasyarakatan.

a. Sistem Sumber Informal

Sistem sumber ini dapat diperoleh dari keluarga, pasangan, teman, tetangga, teman sebaya sesama ODHA, dan pendamping yang bersedia membantu. Bentuk bantuan yang diperoleh berupa dukungan secara emosional, nasehat-nasehat, diskusi pengalaman, dan motivasi kepada ODHA agar selalu mengkonsumsi obat dan menjaga kesehatan.

b. Sistem Sumber Formal

Yaitu Kelompok Dukungan Sebaya (KDS) Puzzle. KDS ini akan menjadi media bagi para ODHA - LSL untuk mendapatkan berbagai penguatan, dukungan dan pendampingan agar mampu meningkatkan kepercayaan diri mereka.

c. Sistem Sumber Kemasyarakatan

Yaitu LSM Puzzle Indonesia itu sendiri yang mempunyai akses dan jaringan kerjasama dengan berbagai lembaga pemerintah dan masyarakat yang terkait dengan program penanganan HIV/AIDS meliputi Kementerian Sosial RI., Dinas Sosial Kota Bandung, Komisi Penanggulangan AIDS Kota Bandung, APN Plus, Rumah Cemara, Jaringan Nasional Gaya Warna Lentera Indonesia (GWLINA), Yayasan Spritia, dan sebagainya.

\section{KESIMPULAN DAN SARAN}

Penelitian ini bertujuan untuk mengetahui kepercayaan diri orang dengan HIV dikalangan Lelaki yang berhubungan Seks dengan Lelaki (LSL). Aspek yang diteliti adalah terkait dengan keyakinan terhadap kemampuan diri, optimis, objektif, bertanggungjawab, dan rasional pada diri ODHA - LSL.

Berdasarkan hasil penelitian pada aspek Keyakinan terhadap kemampuan diri informan menunjukkan bahwa terdapat infoman yang merasa kurang yakin dengan kemampuan yang dimiliki. Hal ini dikarenakan mereka belum terbuka akan status HIV sehingga menjadi hambatan Informan dalam kemampuan dan keyakinan dalam menjalankan aktivitas seharihari dengan baik meskipun berstatus HIV positif.

Pada aspek optimisme terhadap status HIVnya, terdapat Informan yang kurang optimis dengan keadaannya yang berstatus HIV. Walaupun demikian, mereka menyesal dengan kondisinya yang terinfeksi HIV. Informan yang kurang optimis karena tidak mendapatkan dukungan dari lingkungan sekitar 
ataupun orang terdekat. Justru, Informan merasa lingkungan sekitarnya memberikan stigma dan diskriminasi yang sangat kuat kepada para ODHA.

Pada aspek objektivitas terhadap masalah yang dihadapi, hasil penelitian menunjukkan bahwa Informan telah memandang secara objektif permasalahan yang dihadapi berkaitan dengan HIV khususnya stigma yang dirasakan tiap-tiap informan dan terdapat informan yang memandang stigma yang dilakukan terhadap beberapa informan adalah hal yang wajar meskipun stigma itu menyakiti perasaan informan. Hal itu menunjukkan bahwa Informan tidak merasa menjadi beban bagi dirinya sendiri akibat stigma yang mereka dapatkan. Justru mereka menilai masyarakat harus difahamkan secara lengkap dan benar terkait dengan isu penyebaran dan permasalahan yang sesungguhnya.

Pada aspek kemampuan bertanggung jawab menunjukan bahwa informan menerima segala dampak setelah terinfeksi HIV, dan memiliki kemampuan bertanggungjawab yang baik. Informan menerima dampak yang dirasakan akibat terinfeksi HIV walaupun terdapat rasa menyesal yang dirasakan oleh tiap Informan. Adapun dampak yang dirasakan lebih kepada kesehatan berkurang, menghargai hidup dan mengurangi perilaku seks yang beresiko. Selain itu, juga Informan menyesali akibat perbuatannya yang telah melakukan hubungan seks yang beresiko yang menyebabkan terinfeksi HIV.

Pada aspek rasionalitas terhadap masalah yang dihadapi, Informan menunjukkan mampu menganalisis permasalahan sesuai kenyataannya dan membuat keputusan untuk solusi permasalahannya secara realistis. Selain itu, permasalahan dihadapi Informan dengan pemikiran yang dapat diterima sehingga mereka paham bagaimana mereka memecahkan permasalahan tersebut.

Berdasarkan hasil analisis masalah yang terjadi pada setiap aspek kepercayaan diri, maka kebutuhan-kebutuhan yang diperlukan oleh ODHA -LSL di KDS Puzzle adalah pemberian motivasi baik dari keluarga maupun dari anggota Kelompok Dukungan Sebaya (KDS) dan perlunya penguatan atau pembuktian dari sesama ODHA lain bahwa orang dengan HIV dapat hidup layaknya orang normal.

Dalam konteks praktik pekerjaan sosial, kebutuhan pemberian motivasi dan penguatan terhadap ODHA - LSL ini dapat dilaksanakan melalui penerapan Metode Praktik Pekerjaan Sosial Individu dan keluarga (Social Case Work) dan Metode Pekerjaan Sosial dengan Kelompok (Social Group Work).

Melalui Metode pekerjaan sosial dengan individu dan keluarga dapat diterapkan berbagai teknik seperti konseling, pemberian saran (Advice giving), dukungan (support) serta pemberian dorongan, kekuatan dan semangat (encouragement, Reassurance, dan Universalization) agar ODHA mampu mengatasi berbagai permasalahan sehingga menumbuhkan dan meningkatkan kepercayaan dirinya secara positif.

Aktivitas konseling yang dapat dilakukan Pekerja Sosial untuk bekerja dengan ODHALSL yaitu: 1. Beri empati dan dukungan untuk membantu ODHA mengatasi ketakutan dan kecemasan mereka; 2. Bantu ODHA mengatasi perasaan yang terkait dengan ketakutan dan perasaan malu kepada keluarga dan orang lain disekitarnya; 3. Bantu ODHA mengatasi berbagai stigma dan diskriminasi di keluarga/masyarakat; 4. Hubungkan ODHA dengan berbagai jaringan kelompok dukungan lainnya yang diperlukan (Iqbal Putra, Moch 
Zaenal Hakim, Wawan Heryana, 2019).Salah satu teknik metode Pekerjaan sosial dengan kelompok adalah teknik kelompok bantu diri atau Self Help Group dapat juga dilakukan untuk lebih meningkatkan kembali kepercayaan diri ODHA. Teknik ini bertujuan meningkatkan keyakinan kemampuan diri dan optimis Orang dengan HIV LSL terhadap status HIV melalui diskusi atau berbagi cerita tentang masalah maupun pengalaman. Kelompok Bantu Diri ini dapat dijalankan untuk meningkatkan kepercayaan diri ODHA terhadap kemampuan dan kehidupan yang lebih baik, serta dapat menyelesaikan permasalahan yang dihadapi baik secara sendiri maupun dengan dukungan dari lingkungan sekitarnya.

\section{DAFTAR PUSTAKA}

Adi Fahrudin. 2014. Pengantar Kesejahteraan Sosial. Bandung: PT. Refika Aditama.

Anik Maryunani, dkk. 2013. Pencegahan

Penularan HIV Dari Ibu Ke Bayi Penatalaksanaan Di Pelayanan

Kebidanan.Jakarta: Trans Info Media

Dubois Brenda \& Miley. 2014. Social Work An Empowering Profession. United Stated of America : Allyn and Bacon.

Fauziyah, Zahroh Shaluhiyah \& Priyadi Nugraha P. (2018). Respon Remaja Lelaki Suka Lelaki (LSL) dengan status HIV Positif terhadap Pencegahan Penularan HIV kepada Pasangan. Jurnal Promosi Kesehatan Indonesia. Volume 13 Nomor 1 Januari 2018.

Garvin. 2013. Social Group Work. Bandung: STKS Press

Ghufron, Nur dan Rini Risnawati. 2010. TeoriTeori Psikologi. Yogyakarta: Ar-Ruzz Media.

Indah, dkk. 2016. Gambaran Perilaku Pencegahan HIV dan AIDS pada Lelaki Suka Lelaki(LSL) Di Kota Kupang. Jurnal Unnes Journal of Public Health

Iqbal Putra, Moch Zaenal Hakim, dan Wawan Heryana. 2019. Keinginan Bunuh Diri
Orang Dengan HIV/AIDS (ODHA) Dampingan Yayasan PKBI DKI Jakarta. Jurnal Ilmiah Rehabilitasi Sosial. Volume 1 Nomor 1 tahun 2019.

Kartini Kartono. 2009. Psikologi Abnormal dan Abnormalitass eksual. Bandung: Mandar Maju.

Moch Zaenal Hakim. 2019. Model Pelayanan Rehabilitasi Sosial Orang Dengan HIV di Indonesia. Jurnal Ilmu Kesejahteraan Sosial HUMANITAS. Volume 1 Nomor 1 tahun 2019.

Moleong, Lexy J. 2011. Metode Penelitian Kualitatif. Bandung: PT Remaja Rosdakarya Poindexter, Cynthia C. 2010. Handbook of HIV and Social Work : Principles, Practive, and Populations. Canada : Wiley

Peraturan Menteri Sosial Republik Indonesia Nomor 8 tahun 2012

Sugiyono. 2015. Memahami Penelitian Kualitatif. Bandung: Alfabeta.

Solihat, Manap, dkk. 2015. Interpersonal Skill Tips Membangun Komunikasi dan Relasi. Bandung : Rekayasa Sains.

\section{Internet}

http://www.pusdatin.kemkes.go.id. (diakses pada 11 Agustus 2018) 